\title{
熟練作業者の動力学特性に基づいた力制御による柔軟なリング状 部品の取り付け作業
}

\author{
福 本 靖 彦* $1 * 2$ 原 田 研 介*2*3
}

\section{Force Controlled Assembly of a Ring-shaped Elastic Part Based on Dynamic Characteristics of Skilled Workers}

\author{
Yasuhiko Fukumoto*1*2 and Kensuke Harada*2*3
}

\begin{abstract}
This paper proposes a novel method for assembling a ring-shaped elastic part to a cylinders' outer groove by using an industrial robot. To assemble a ring-shaped elastic part, forces acting on an elastic part should be made as small as possible. In our proposed method, while the force control strategy itself is determined based on the human characteristics, the parameters of the controller is determined by using a numerical optimization. First, the position data and the force data while a human demonstrates the assembly are measured. Then they are qualitatively analyzed and two control methods are derived. However, we do not obtain the parameters of the force control from the human data. This is because the performance, for example the response characteristics, of robots is different from that of human and the parameters obtained from human data are not necessarily suitable for robots. Thus we obtain the parameters by an optimization with the downhill simplex method which is feasible for an optimization based on actual machine. To confirm that the applied force is significantly reduced, we conduct experiment and compare two force control methods.
\end{abstract}

Key Words: Industrial Robot, Assembly, Force Control, Ring-shaped Flexible Part

\section{1. 緒言}

油圧シリンダ部品の組み立て工程などにおいて, 円柱状のワー クにリング状のゴムパッキンを取り付ける作業がある. 特に剛 性の高いパッキンにおいて，その取り付け作業は重労働であり 自動化の要求は大きい. また，パッキンは傷や永久ひずみなど によって損傷があるとシール性能が劣化して油などが漏れる恐 れがあるため, 取り付け時にはパッキンに過大な力を掛けない ことが望まれる，これまで筆者らはロボットにより柔軟性を有 するリング状部品の円柱状ワークへの取り付け問題について検 討を行ってきた $[1] 〜[3]$.

このような問題に対して，本論文はパッキンなどの柔軟なり ング状部品に作用する負荷を低減するための手法を新たに提案 する.ヒトが作業を行う場合，ヒトは扱う対象に余計な負荷を

原稿受付 2017 年 5 月 2 日

*1香川県産業技術センター

$* 2$ 大阪大学大学院基礎工学研究科

$* 3$ 国立研究開発法人産業技術総合研究所

${ }^{* 1}$ Kagawa Prefectural Industrial Technology Research Center

${ }^{* 2}$ Graduate School of Engineering Science, Osaka University

${ }^{* 3}$ Intelligent Systems Research Institute, National Institute of Advanced Industrial Science and Technology (AIST)

本論文は有用性（要素分野）で評価されました。
加えないよう丁寧に作業を行っている，一方，ロボットが作業 を行う場合，金属など非常に丈夫な対象物を扱うのであれば多 少大きな力が作用しても対象物を破壊することはないが，本論 文で対象としているパッキンなどの柔軟な部品の取り付け作業 では，前述のと抢り対象物にダメージを与えないことを考慮す る必要がある。そこで本研究では, ヒトによる柔軟な部品の取 り付け時の手先の動きや手先に作用する力を解析し，それを基 にロボットに力制御を実装することでヒトの動力学特性に基づ いた取り付け方法について検討する.

ヒトの特性を基にロボットに力制御を行わせている研究の例 として [4]〜 [14] がある. 浅田ら [4] や望月ら [5] はヒトが作業を 行うときの力や位置のデータを解析してハイブリッド制御のパ ラメータを得ており，板橋ら [6] や津坂ら [7] は同様にインピー ダンス制御のパラメータを得ている. Ajoudani ら [8] はヒトの 力と位置の関係ではなくヒトの筋電位をセンシングすることで ヒトのインピーダンスを推定してロボットのインピーダンス制 御のパラメータとしている. 田中ら [9] はヒトの作業データか ら位置の目標軌道を抽出するとともに，対象物等の環境の摇ら ぎに対応するためのセンサフィードバック則も同時に得ている. Lee ら [10] は位置だけでなく力の目標軌道も抽出し，ヒトの作 業データから得たインピーダンスを用いたインピーダンス制御 を行って環境の摇らぎに対応している，また，榎本ら [11] や尹 
ら [12] はマスタ・スレーブ型のロボットにおいてスレーブにイ ンピーダンス制御を実装しておき，それをマスタ側からうまく 操作するときの操作入力をタスクとして抽出する方法を提案し ている. Gribovskaya ら [13] や Racca ら [14] はヒトが作業を 行うときの位置と力のデータを再現するため, インピーダンス 制御の剛性パラメータを動的に変更することでヒトの位置と力 の両方をバランス良く追従させている.ここで, これらの従来 手法においては, インピーダンス制御におけるインピーダンス パラメータをヒトの動力学的特性に基づいて決定している. し かしながら, 従来の手法においては, 以下に示す二つの問題点 が存在する．まず一つめは，仮にヒトの手のインピーダンス特性 が得られたとしても, それがロボットが作業を行う際の最適な インピーダンス特性とは限らないということである. 次に二つ めは，ヒトの作業中における手先のインピーダンス特性を得る こと自体が容易ではない [15] [16] ということが挙げられる.こ のような問題点を考慮し, 本研究ではヒトのインピーダンス特 性を完全にロボットに移植することを目指すのではなく, ヒト の動特性の定性的な解析からロボットの力制御則を導出し, そ の上でロボットに適した力制御のパラメータを最適化問題を解 くことで得ることを考える。これにより，ヒトの特性を基にし つつロボットの作業性も考慮した制御が得られると期待される.

続いてパッキン取り付けの問題を柔軟物操作の問題としての 側面から考える。一般に柔軟物操作においては対象物体の変形 などをモデル化して解析するアプローチと, 対象物体の挙動は ブラックボックスのままヒトが作業を実演したデータから作業 方策を導くアプローチがある [17]. 本研究においては, リング状 部品の三次元的な変形, 閉ループ機構, 摩擦力といった複雑な 要因により前者のアプローチを取ることは難しく, 後者のアプ ローチによりヒトの作業における定性的な解析から制御方策を 導く. また, 柔軟物操作の操作対象では布, 紙, 薄板などの平面 物体や，ひもや針金などの線状物体を扱う例は比較的多い [17] が, 本研究が対象とするリング状の柔軟な対象物は対象物自体 が閉ループを有するため, 線状物体とは別の取り扱いをする必 要があるが, リング状の柔軟対象物を扱った例は少ない.ここ で, ラミレスら [18] や村瀬ら [19] はリング状の柔軟部品の組立 作業の研究を行っているが, 比較的剛性が低いリング状の対象 物を想定しているため, 本論文で対象としているパッキンへの 適用は難しいと考えられる。このほか, デンソー [20] や三菱電 機 $[21]$ などの特許では複数本の爪でリングを内側から広げ, 取 り付け溝の位置で押し出す機構が提案されており, SCHUNK は 6 本のツメでリングを内側から六角形状に広げ, 取り付け溝 の位置で 3 本ずつ順番に抜くことでうまく取り付け溝にはめ込 むグリッパORG [22] を販売しており, 日産自動車 [23] やガス ター [24] の特許ではテーパのついた筒状のジグを使ってリング 全体を弾性変形させながら押し広げ, 取り付け溝の位置で開放 するタイプの機構が提案されているが，これらも剛性の低いリ ングを想定しており本研究の対象とは異なる.

以下, 本論文では 2 章で対象とするパッキン取り付け作業に ついて述べ， 3 章でロボットによる取り付けの概要を述べ，4 章 でヒトの動力学特性に基づいた力制御則の提案を行い，5章で 提案手法をロボットに実装して実験により有効性を確認した結
果を示し， 6 章でまとめを述べる.

\section{2. パッキン取り付け作業}

Fig. 1, Fig. 2, Fig. 3 にはヒトが油圧シリンダ用のパッキ ンなどに用いられる柔軟なリング状の部品を円柱部品に取り付 ける際の三種類の方策について，その概要を示す. Fig. 1 には 最も直感的な手法として, いったんパッキンを半径方向に均一 に伸ばし，そのうえで円柱に組み付ける手法 [20]〜 [24] を示す. ただし，この手法では最初にパッキンをなんらかの方法で均一 に伸ばす必要がある。また，この手法は通常特殊工具を用いる 必要があり，パッキンに比較的大きな弾性変形を生じさせなく てはならない. それに対して, 油圧シリンダ用のパッキンの取 り付け作業ではパッキンを必要以上に弾性変形させないことが 求められる，傷や永久ひずみの恐れがあることに加え, 剛性が 高いため大きな伸びを作ること自体が困難であることも理由で ある.そのため，取り付けにおいては全体を広げる Fig. 1 のよ うな方法ではなく，パッキンに必要以上の弾性変形を加えない Fig. 2 のような方法が一般的である.この手法では，最初にパッ キンの一部をシリンダの縁にひっかけ，そのうえで手を使って パッキンの一部を伸ばすことにより，パッキンがシリンダに掛 かる領域を徐々に増やす。パッキンがシリンダの全周にわたっ て掛かると，パッキンをずらして溝にはめる．この手法ではパッ キンの伸びが抑えられることで伸ばすための力もある程度減る

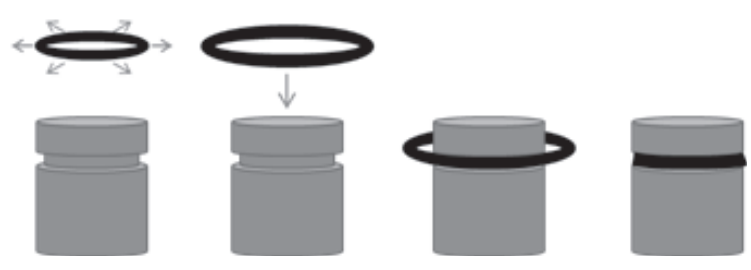

Fig. 1 An intuitive assembly method of a ring-shaped packing by a human worker where a packing moves straight down toward a cylinder

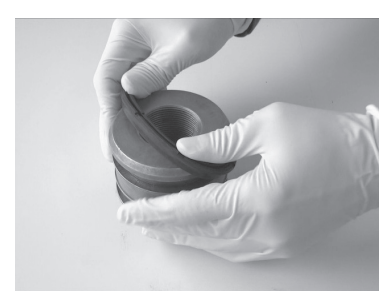

(a)

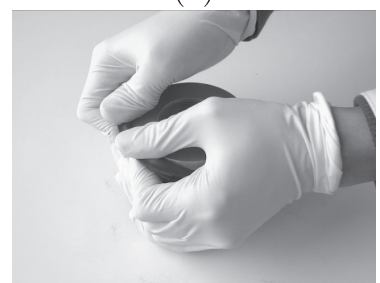

(c)

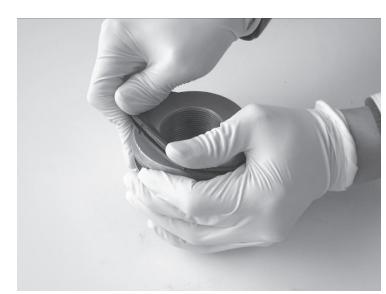

(b)

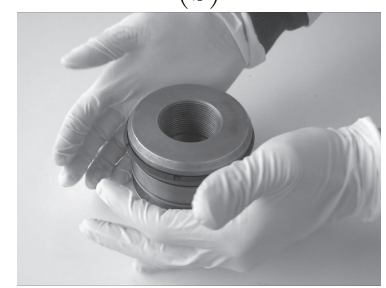

(d)
Fig. 2 An assembly method by a human worker without using a bar-like tool in which he/she still has to apply large force onto the packing 


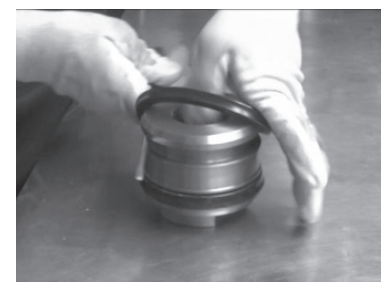

(a)

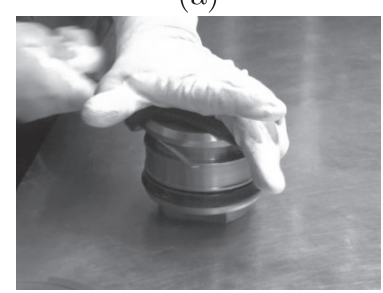

(c)

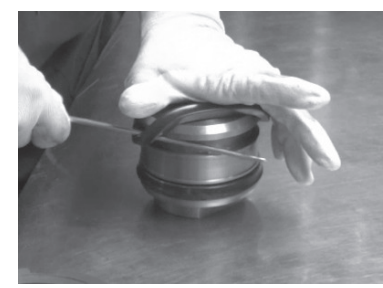

(b)

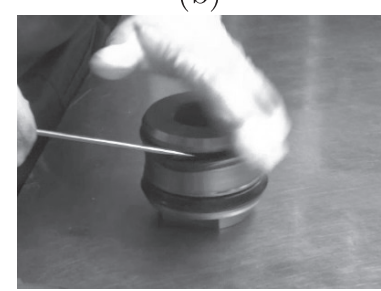

(d)
Fig. 3 Assembly of a ring-shaped packing by a human worker using a bar-like tool where (a) he/she first sets a ringshaped packing on a cylindrical work, (b) moves the tool along the surface of the cylinder to assemble the packing, (c) rotates the cylindrical work, and (d) finally completes the assembly

ことが期待できる.しかしながら，ここではさらに少ない力で パッキンの取り付けが可能になるように，細い棒状のッールを 用意して腕全体で無理なく力をかけられるようにすることを考 える. Fig. 3 は，この細い棒状のッールを利用した例を示す．こ の手法では, ッールをパッキンに引っ掛けた状態で取り付け溝 に添わせて油圧シリンダの周囲を一周することで取り付け作業 を行うものである.まず, Fig. 3 (a)のようにパッキンをワーク に添えた状態で，ッールをパッキンに引つ掛けて油圧シリンダ の取り付け溝の上端部にセットする。ツールの角度は作業台と ほぼ平行である。そこからッールを溝に添わせて少し動かすと Fig. 3 (b) の状態になる. そこから全体を少し逆方向に回して Fig. 3 (c) のように角度を戻して, 再度ツールのみを動かして パッキンの残りの部分をはめ込むと Fig. 3(d)のと㧍り取り付 けが完了する，途中で全体を逆方向に回転しなおす過程を挟ん でいるのは，そうしないとッールを持った手がワークの奥の側 まで回り込む結果, 腕が力を入れにくい姿勢になって作業性が 悪くなるためである。 パッキンの取り付け作業では, 油圧シリ ンダの全周にわたってパッキンを取り付け溝に嵌めるが，それ を実現するには半径方向に押し広げて溝上部の径の広い部分の 外側に持っていくことと, 高さ方向に押し下げて溝の高さまで 持っていく二つの操作が必要である。この細い棒状のッールを 用いた方法では，Fig.4(a)のようにッールによってパッキン を径方向に拘束しながら, 同時に Fig. 4 (b) のように高さ方向 への拘束も実現して㧍り，そのままツールを周方向へ動かして いくと二つの拘束により少しずつパッキンが半径方向に広げら れつつ溝の高さに押し下げられて溝に入っていく仕組みとなっ ている.

\section{3. ロボットによる取り付け方法}

2 章において Fig. 3 で示した棒状のツールを使った取り付け

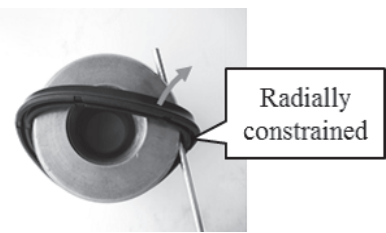

(a)

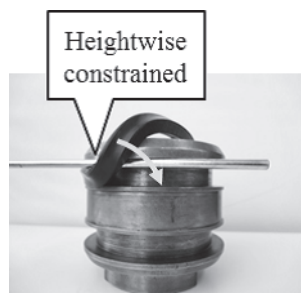

(b)
Fig. 4 Explanation of mechanism to assemble a ring-shaped packing where the tool constrains the motion of a ringshaped packings in both radial and directions

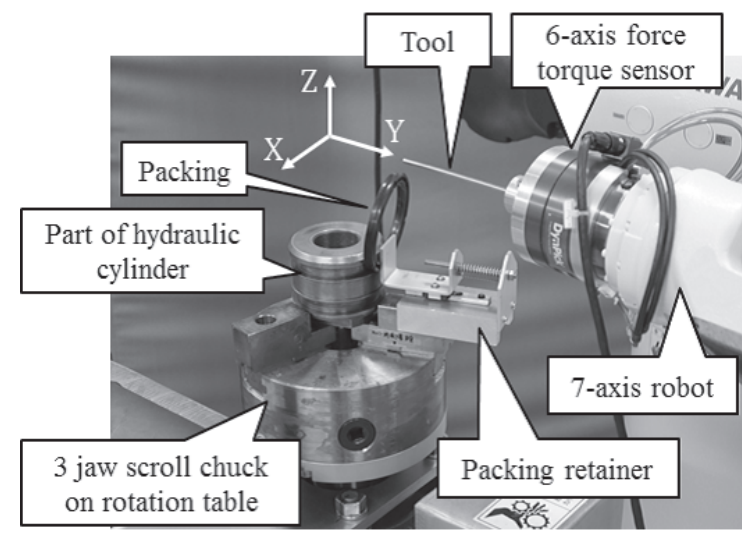

(a) Full view

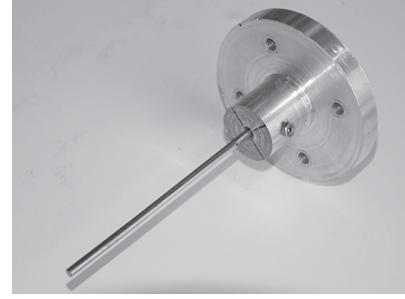

(b) Tool

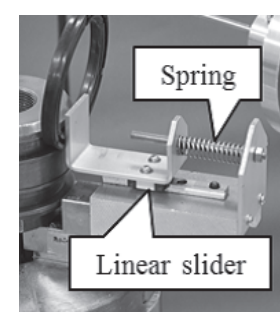

(c) Packing retainer
Fig. 5 Experimental system

手法をロボットにより自動化することを考える $[1]$. 本章では比 較実験として用いる動作教示のみを用いてロボットを動作させ る手法を説明し，次章において力制御を導入することにする。ロ ボットに動作を教示する際には，Fig. 3 (b) から Fig. 3 (c) にお けるワークの姿勢を調整する過程を省き，ワークを固定したう えでッールをワークに沿って一周させる動作が比較的容易に実 現可能である。しかしながら，この手法ではロボットがワーク の奥まで手を伸ばさなくてはならず，ロボットに対して広い動 作範囲が要求される，そこで，本研究ではツールではなくワー クを動かすことを検討し，ワークを保持した上で鉛直軸まわり に回転するジグを用意して，ッールはジグに固定することにし た.この実験装置を Fig. 5 (a)に示す。この装置においては, 双 腕ロボット MOTOMAN-SDA10D (安川電機) の片腕（7 軸） を用い，その先端に安川電機の MotoFit オプションにより付属 する 6 軸の力・モーメントセンサ WEF-6A1000-30-RG24 を 搭載し，その先に棒状のツールを取り付けている。ッール部は 


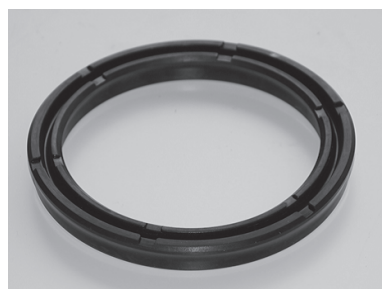

(a) Full view

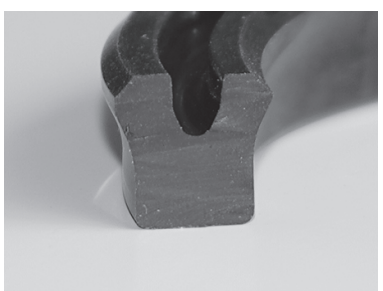

(b) Cross-section
Fig. 6 Appearance of a packing

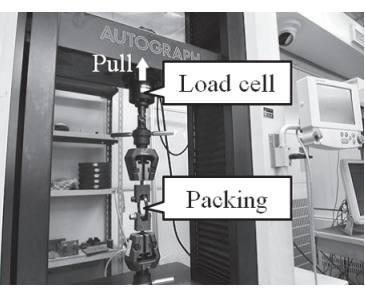

(a) Full view

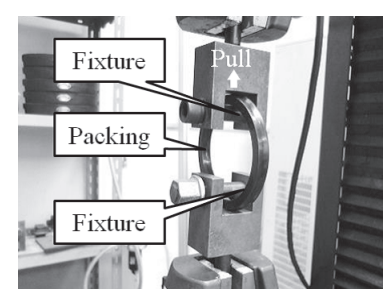

(b) Fixture part
Fig. 7 Setting of a tensile test

Fig. 5 (b) のように，丸棒と，力・モーメントセンサを接続する フランジ部によって構成されている。丸棒はクロムバナジウム 鋼製で全体焼入れとクロムメッキが施されたものであり，直径 は $4[\mathrm{~mm}]$ で表面粗さは $R_{a}$ が $0.31[\mu \mathrm{m}]$ である. フランジ部 はアルミニウム製であり，七ットボルトで丸棒を固定している. 丸棒部とフランジ部を組み合わせた状態では，全長 $160[\mathrm{~mm}]$ で重量 $169[\mathrm{~g}]$ である. なお， 6 軸の力・モーメントセンサは 本章では用いておらず，次章で導入する力制御において用いる. テーブルに設置した回転テーブルの上に固定した 3 指スクロー ルチャックによりシリンダを固定している，また， 3 指スクロー ルチャックの指の一つには Fig. 5 (c) のようなパッキン押さえ機 構を取り付けており，スクロールチャックを閉じると同時にパッ キン押さえ機構がパッキンをシリンダの側面の溝の部分に押し 付けるようにした.

本研究は剛性の低いO リングだけではなく剛性の高いパッ キンにも対応できることを特徵の一つとしている．本研究の実 験ではそのようなパッキンの例として Fig. 6 (a)のような内径 $70[\mathrm{~mm}]$, 外径 $85[\mathrm{~mm}]$, 厚さ $9.2[\mathrm{~mm}]$ のニトリルゴム製パッ キンを用いた。 また Fig. 6 (b) はその断面形状である. 本パッキ ンの剛性を示すため Fig. 7 のような簡易実験を実施した. これ はパッキンの中に直径 $12[\mathrm{~mm}]$ の丸棒を 2 本通して万能試験機 AG-50KND（島津製作所）に取り付け，引張試験を行ったとき の変位と力の関係を調べたものであり，剛性の参考值を確認す るためのものである. 比較のため, 比較的剛性が低いリングの例 として，ほぼ同じ内径である内径 $69.4[\mathrm{~mm}]$, 外径 $75.6[\mathrm{~mm}]$, 線径 $3.1[\mathrm{~mm}]$ のニトリルゴム製 $\mathrm{O}$ リングについても同様の測 定を行った. Fig. 8 が測定結果である. 変位が $0 〜 33[\mathrm{~mm}]$ 付 近までは，パッキンがFig.9 (a)のような円形から Fig. 9 (b)の ような伸びた形状に変形するまでの領域で, パッキンの内周の長 さはほぼ変わらない曲げの変形が起きている，その後 $33[\mathrm{~mm}]$ 付近を超えて傾きがより大きくなる領域は Fig. 9 (c) のように内 周が伸びる形で伸びていく変形となり, 主に伸びの変形が起き

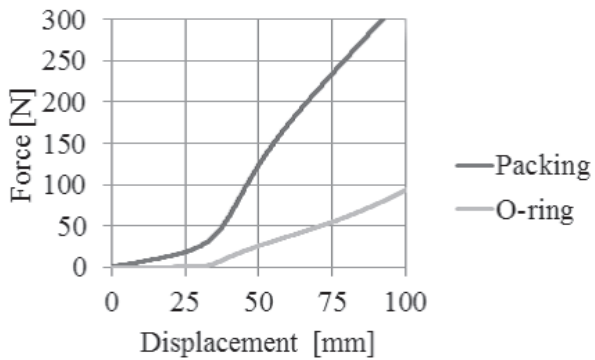

Fig. 8 Relationship of displacement and force measured by an universal testing machine

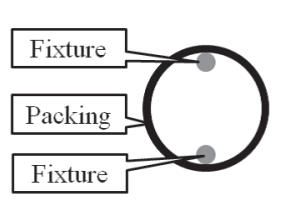

(a)

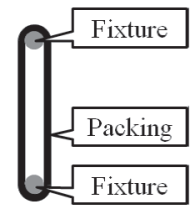

(b)

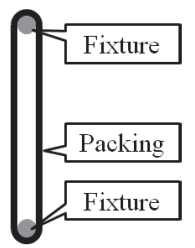

(c)
Fig. 9 Deformations of an elastic ring: (a) shows the case where an initial shape and the displacement is $0[\mathrm{~mm}]$, (b) shows the case where the inner peripheral length is invariant and the displacement is about $33[\mathrm{~mm}]$ and (c) shows the case where the inner peripheral length is stretched and the displacement is more than $33[\mathrm{~mm}]$

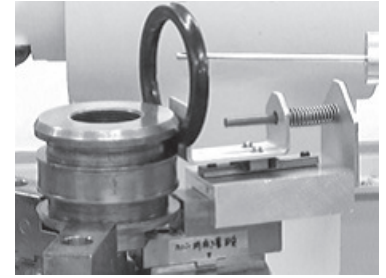

(a)

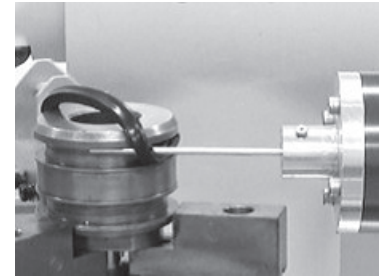

(c)

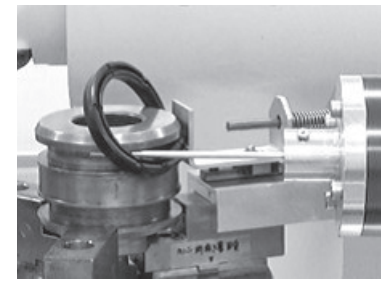

(b)

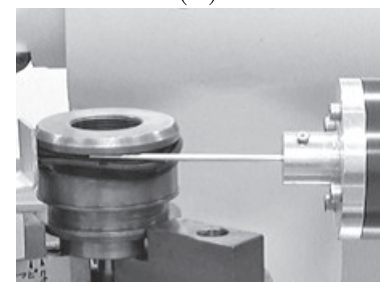

(d)
Fig. 10 Assembly by a robot where (a) the robot sets the tool mounted on the arm, (b)the chuck holding the work starts rotating, (c) the packing is been installed, and (d) finally the packing is completely assembled

ている.いずれの変形でも O リングよりパッキンのほうが剛性 が高いが，取り付け作業時に問題になるのは特に後者の変形領 域であり，同じ伸びを得るのに拈よそ 5 倍の力が必要となって いる. 加えて，リングの取り付け時にはリングの内面が取付溝 の外側の部分を超えるところまで伸ばす必要がある。取り付け 溝の外側の部分の径はリングの外径と近く設計されるため, リ ングの内径と外径の差が大きい，すなわち太いリングほど取り 付け時に大きな伸びを必要とする。したがって本パッキンは従 来手法 [18]〜 [24] による取り付けが非常に困難である. 
ロボットによる作業の様子を Fig. 10 に示す. Fig. 10 (a) に 示すように，パッキンを指とシリンダの側面の間に挟んだ状態 で, 棒状のッールを水平にしてパッキンの輪の中に通しておく. この状態から, Fig. 10 (b) に示すように棒状のツールを鉛直下 方向に下げて溝内の上端に接触させ，Fig. 10 (c) に示すように 回転テーブルを回転させる. これにより, ッールに沿ってパッキ ンが押し下げられることでパッキンの取り付けが行われる。こ の手法では, 最初にツールをセットする過程（Fig. 10 (a) から Fig. 10 (b) の間の動き) と Fig. 10 (d) 以降で取り付けが終わっ た後にツールを抜き取る過程においてのみロボットが動作して いる.

以上の取り付け方法で実際にロボットによる取り付けを行う と, 100 回の取り付け実験で 100 回とも取り付けに成功し, 成 功率については良好であった。

\section{4. パッキン取り付け時に発生する負荷の低減}

次に，ヒトが作業を行う際には，無意識のうちに手先が発生 する力をなるべく小さくしていることが予想できる. また，手 先が発生する力を小さくすることは, パッキンの弾性変形を小 さくすることと直結する，このため，ここでは次のステップとし てパッキンの弾性変形をなるべく小さくすることを目的として, ヒトの作業デー夕を参考にした力制御手法を提案する. ここで, 前章の Fig. 10 では最初にツールをセットする過程と, 取り付 けが終わった後でッールを抜き取る過程のみにおいてロボット が動作しているが，本章に扔いては，この二つの過程の間でロ ボットが加える力を制御することによって, パッキンの弾性変 形をなるべく小さくすることを考える.

Fig. 11 (a) は，ロボットに前章に扔ける Fig. 10 で説明した 動作によりパッキンの取り付けを行った際にロボットの手首に 搭載した力・モーメントセンサの出力をプロットした図である. 座標系は Fig. 5 (a) の中で示した向きであり, ツールの先端か ら根元へ向かう向きを $\mathrm{Y}$ 方向, 天頂方向を $\mathrm{Z}$ 方向, $\mathrm{Y}$ 方向と $\mathrm{Z}$ 方向に直交する向きで系が右手系になる向きを $\mathrm{X}$ 方向として それぞれの方向に作用する力とその 3 方向の合力をプロットし ている，比較のためヒトが同じッールを持ち，同じ旋回ジグを 用いて取り付けを行った結果を Fig. 11 (b) に示す.な㧍ここで この作業を行ったのは棒状のッールを用いた Fig. 3 によるパッ キン取り付け作業を 4 年以上実施している熟練作業者である.

まず 3 方向の合力に着目すると, ロボットでは $71.2[\mathrm{~N}]$ の力 が作用しているのに対して, カ・モーメントセンサに棒状のッー ルを取り付けた装置を作成し，その装置をヒトが把持してパッ キンの取り付け作業を行ったところ，ヒトでは $16.7[\mathrm{~N}]$ で取り 付けができており 4 倍以上の差が存在した。 つまり, この方法 でのロボットによる取り付けではパッキンに大幅に過大な負荷 を与えていることが分かった。これより, 動作教示のみを行っ た場合のロボットの動作は改善の余地が大きい.

続いて $\mathrm{X}, \mathrm{Y}, \mathrm{Z}$ それぞれの成分についても比較し，より詳 細に測定結果を検討した。 ロボットの取り付け時に計測された 力の成分は大きい順に $\mathrm{Y}, \mathrm{X}, \mathrm{Z}$ 方向となっている. $\mathrm{Y}$ 方向に ついてはロボットでは最大の成分である一方でヒトの場合には ほぼゼロとなって抢り両者の差が最も顕著である.X方向につ

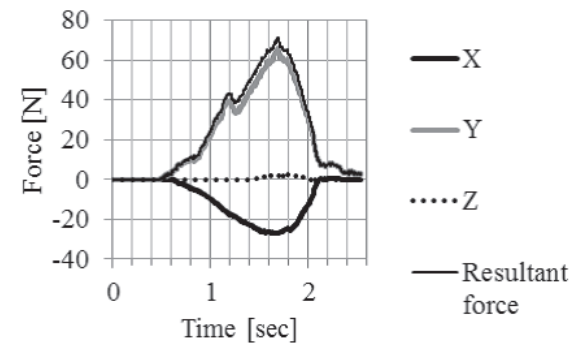

(a) Force in assembly by a robot

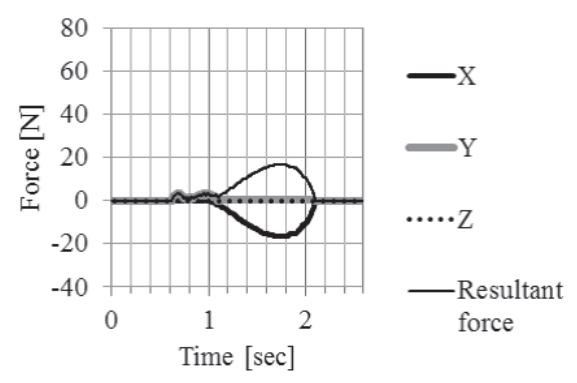

(b) Force in asembly by a human

Fig. 11 Measuerd forces of a robot and a human during assembly where remarkable differences can be observed especially in $\mathrm{X}$ and $\mathrm{Y}$ directions

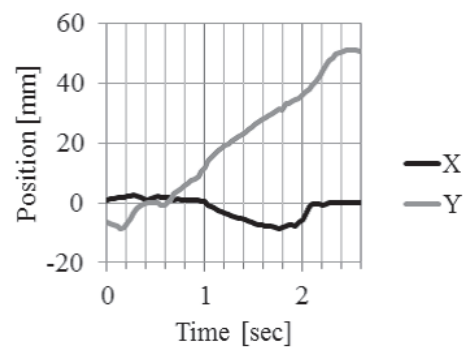

Fig. 12 Tool trajectory of assembly by a human where X component shifted to negative direction and finally returned to zero, and its $\mathrm{Y}$ component continuously increased

いてはヒトでもゼロとまではいかないが大きな差が観測されて いる. 一方 Z 方向については若干の差は見られるものの, どち らもあまり大きな值ではなかったので，Y 方向と $\mathrm{X}$ 方向のみに ついて対策を検討することとした。

またヒトの取り付けに押いては, 取り付け中に手先の位置が 変動していることが観測された。したがってヒトは受けた力に 応じて手先をうまく動かすことで負荷を逃がしていると考えら れ，その動力学特性の定性的な解析からロボットによる取り付 けの改善方策を検討することを考える，そこでヒトの手先の動 きを上方から $30[\mathrm{fps}]$ のカメラ 1 台で撮影し, 手先の動きを簡 易に計測した. Fig. 12 は測定結果であり Fig. 13 は測定時の 撮影例である.

次に, Fig. 11 (a)に示したロボットによってパッキンの取り付 けを行った際に手先が発生する力を, Fig. 11 (b) に示すヒトが棒 状のツールを持って実験した際に手先が発生する力に近づけるこ とを目的として，ロボットの制御則を構築する. $p=\left[\begin{array}{ll}p_{x} & p_{y}\end{array}\right]^{T}$ 


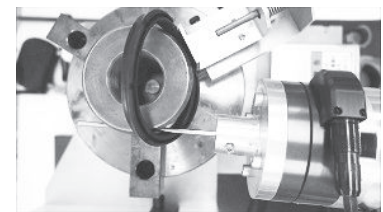

(a)

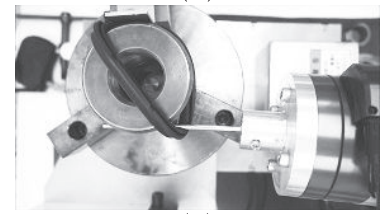

(c)

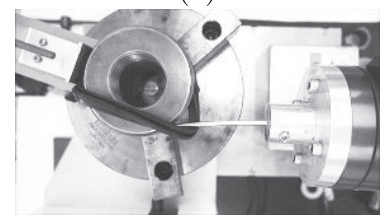

(e)

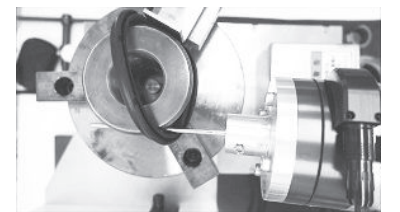

(b)

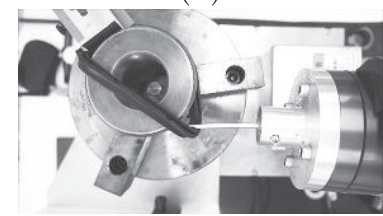

(d)

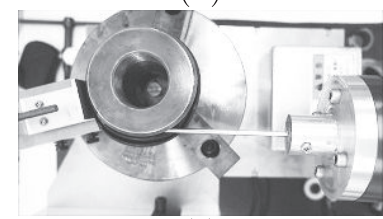

(f)
Fig. 13 Movement of the tool when human performed a packing assembly

を手先の位置の初期位置からの変位を表すべクトルとして $\dot{p} を$ その時間に関する一階微分とする. また $f=\left[\begin{array}{ll}f_{x} & f_{y}\end{array}\right]^{T}$ は外力 を表すべクトルであり, Fig. 11, Fig. 12 に打いて最も負荷の大 きかった Y方向のデー夕を見ると, ヒトが力を受けた向きに手 先を動かしていることから， ロボットでも力を受けた向きに手 先速度を与える，つまり $d_{y}$ をパラメータとし，

$$
\dot{p}_{y}=d_{y} f_{y}
$$

としてカに比例した速度を与えるダンピング制御を実装するこ とで一定の負荷軽減ができると予測する.

続いてX 方向に着目すると, Fig. 11 抢よび Fig. 12 のと扔り ヒトは X 方向では力が作用するとその方向に手先が動き, 力が 抜けると元の位置に戻っていることから, ロボットでも比例係 数 $k_{x}$ により

$$
p_{x}=k_{x} f_{x}
$$

として力に比例した位置の変位を与える剛性制御を実装して剛 性を持たせることで負荷軽隇ができると予測した。

パラメータ $d_{y}, k_{x}$ については滑降シンプレックス法 $[25]$ に より取り付け時のピーク負荷が最小となる值を探索することと した．滑降シンプレックス法は多変数の最適化に対応しており， また最急降下法などの勾配法と違って評価関数の微分值がなく とも評価值のみ得られればよいという点が特徴である. 本件に おける評価值であるピーク負荷は, 実際にそのパラメータで取 り付け実験を行うことにより得ることができる. 以上により定 性的にはヒトの作業データを参考にしつつ, パラメータチュー ニングについてはヒトとロボットの応答性能などのハードウェ ア上の違いを考慮してロボットにとって最適なものを選ぶこと ができる。なお，一般に力制御のパラメー夕を実験によって最 適化するのは非常に大きな手間を要する. Hirai ら [26] や山野 辺ら [27] も滑降シンプレックス法による力制御パラメータの最
適化を実施しているが，これらの研究では実験ベースでのパラ メータ探索の試行回数を減らすため, 前段階としてシミュレー ションによる探索を行ってあらかじめ拈拈よその検討を行って から, 実機での探索を行っている. 一方, 本研究においては柔 軟物の閉リンク機構で摩擦を伴うという複雑な対象を扱ってい るためシミュレーションが困難であるが, ヒトの作業の定性的 な観察によりパラメータは二つだけに抑えられているので実験 だけによる最適化も十分実現可能となっている.

\section{5. 力 制御 実 験}

ロボットの手先に速度制御ベースのダンピング制御㧍よび岡 性制御を実装してパッキンの取り付け実験を行った，用いたパッ キンおよび取り付け先の金属部品は直径 $85[\mathrm{~mm}]$ の油圧シリ ンダ用のもので Fig. 2 13 と同じものである. ロボットは安川 電機製 MOTOMAN-SDA10F を利用した．本ロボットはオプ ションの MotoPlus 機能により $4[\mathrm{~ms}]$ 周期で速度べースの移動 命令を与えることができるのでこれを利用し, 式（1）の実装に ついては式（1）で計算される速度值をそのまま速度の目標值と し, 式（2）の実装は式（2）の両辺を微分した後に制御周期を $T[\mathrm{~ms}]$ として右辺を後退差分により離散時間化した

$$
\dot{p}_{x}(t)=\frac{k_{x}}{T}(f(t)-f(t-T))
$$

で得られる速度を速度制御の目標値として実装することとした。 $\mathrm{Z}$ 方向や回転方向については目標速度をゼロとしてこれらの方 向には動かないようにした。

実験ではロボットによる次の二つの取り付け手法を試した。

\section{制御 1}

X 方向：目標速度をゼロとする.

Y 方向：式（1）のダンピング制御を実装する.

制御 2

$\mathrm{X}$ 方向：式（3）の剛性制御を実装する.

$\mathrm{Y}$ 方向：式（1）のダンピング制御を実装する.(制御 1 と同様)

制御 1 は Y 方向の対策効果があるかどうかを検証し, 制御 2 はそれにX方向の対策を追加することでさらに低減効果が得ら れるかを検証するものである。 な挹 Fig. 11 (a) に示したロボッ トの手先を動かさない場合の手先負荷を見るとY 方向の負荷が 負荷全体に対して支配的になっており，X方向の力だけを低減 しても全体に及ぼす影響は軽微であるため X 方向の対策だけを 行った場合の効果については検証しなかった.

パラメータ $d_{y}, k_{x}$ については滑降シンプレックス法により決 定した。最適化に扔ける評価值はパッキン取り付け時の負荷の ピーク值を用いた。この值は実際に候補となるパラメータでロ ボットによる取り付け実験を実施することで得られるが，同じ パラメータでも試行のたびに值が変動することが予想されたた め, 取り付け実験は 3 回実施し, その 3 デー夕の平均值を用い た。パラメータによっては取り付け実験で手先が振動する場合 があるが，これはパッキンへの負担や安全性の面から望ましく ないため, 振動が発生した場合はペナルティとして十分大きな 值を評価値として与えることとした．制御 1 における最適化は 
10

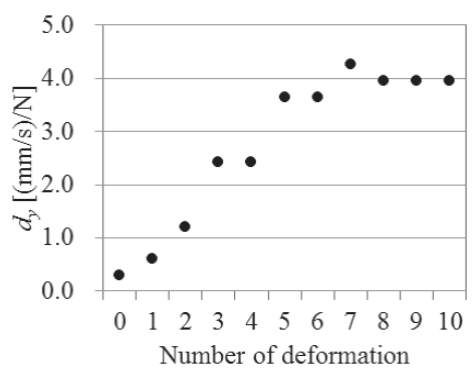

(a) Transition of the best parameter in each simplex

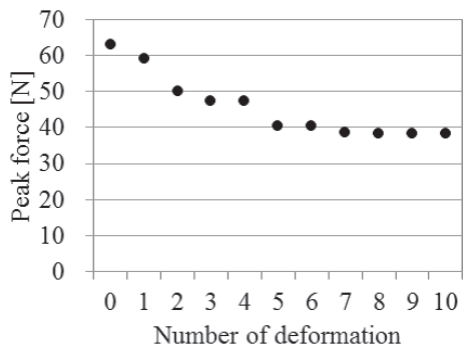

(b) Force values which are the lowest values in each simplex

Fig. 14 Result of an optimization for "Control 1"

1 変数 $\left(d_{y}\right)$ の最適化であるので, 2 頂点からなるシンプレック スにより探索を行い, 制御 2 に扔ける最適化は 2 変数 $\left(d_{y}, k_{x}\right)$ の最適化であるので 3 頂点からなるシンプレックスにより探索 を行った. 探索の停止条件はシンプレックスが 3 回変形しても 最良の頂点が更新されなかったときとした，なお滑降シンプレッ クス法で多次元の最適化を行う場合, 何らかの理由で最適でな い点で停止することがあるため, 制御 2 では探索が停止した点 とその近傍の点を初期值として，再度探索を実施した。

まず制御 1 における $d_{y}$ の最適パラメータを探索した。探索の 初期值は安全のため十分低いゲインを選ぶこととし，Fig. 11(a) に示した手先を動かさない場合の Y 方向の負荷の最大值であ る 65.8 [N] がロボットの手先に作用したと仮想的に考えたと きに, 比較的遅い速度である手先速度 $10[\mathrm{~mm} / \mathrm{s}]$ を発生させ るようなパラメータ值である $0.152[(\mathrm{~mm} / \mathrm{s}) / \mathrm{N}]$ と，その近傍 点 1 点からなるシンプレックスを初期シンプレックスとした.

Fig. 14 (a) はパラメータ空間上でシンプレックスの中の最良点 が推移していく様を示して抢り, 徐々にゲイン $d_{y}$ が大きくな り $4.0[(\mathrm{~mm} / \mathrm{s}) / \mathrm{N}]$ で落ち着いている. そして Fig. 14 (b) はシ ンプレックス中の最良点の評価值の推移を示しており, 最適化 が進むにつれて取り付け負荷が下がっていくことが確認された。 な押，本最適化では停止するまでにシンプレックスを 10 回変 形させており，合計 18 パラメータについて実験を行った。

続いて制御 2 における最適パラメータを探索した。 $d_{y}$ の初 期值は制御 1 での最適パラメータの值を参考にすることとした が, X 方向への制御も加わったときに不安定度が増す可能性が 考えられるため, 安全のためゲインを落として制御 1 で得られ た最適パラメータの半分の值を初期値として採用した．また $k_{x}$ の初期值は手先を動かさない場合の X 方向の負荷の最大值であ る $27.1[\mathrm{~N}]$ において比較的小さい位置の変位として $1[\mathrm{~mm}]$ の 変位がある場合を想定した $0.037[\mathrm{~mm} / \mathrm{N}]$ を採用した.シンプ

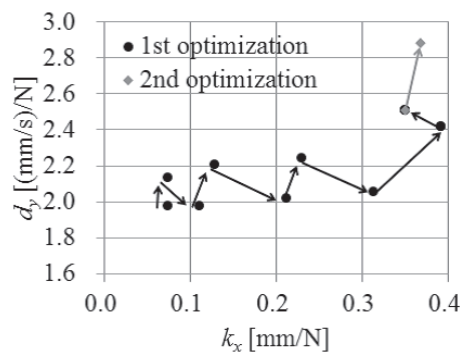

(a) Transition of the best parameter in each simplex

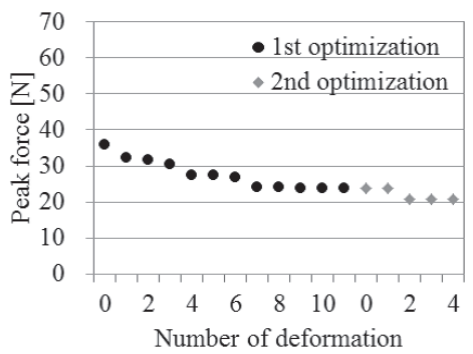

(b) Force values which are the lowest values in each simplexes

Fig. 15 Result of an optimization for "Control 2"

レックスの残りの 2 点はこの近傍の点とした. シンプレックス の最良点が変化する様子を Fig. 15 (a) に示し, シンプレックス の最良点の評価值の推移を Fig. 15 (b) に示す. 最終的に得られ た $d_{y}$ は制御 1 の最適化で得られた值よりも低いゲインとなっ ておりX方向とY方向が抢互いに完全に独立しているものでは なく相互作用が存在していることが分かる. 1 度めの最適化で は初期シンプレックスでも最適化 1 の最適パラメータでの評価 值よりも良い值になっており，X方向の対策が非常に有効であ ることが示唆されている. さらに最適化が進むにつれて評価值 はさらに改善が進んでいる. また 1 度めの最適化で停止した後 に実施した 2 度めの最適化においても評価値はさらに $13.0 \%$ 改 善しており, 再最適化の効果が見られた. なお 1 度めの最適化 では停止までのシンプレックスを 11 回変形させる中で 28 パラ メータについて実験した．続く 2 度めの最適化ではシンプレッ クスを 4 回変形させ 9 パラメータについて実験を行った.

以上の探索で得られた最適パラメータでの取り付けについて 詳細に検証した。まず取り付け実験を制御 1 と制御 2 それぞれ について 10 回ずつ行った。この実験で取付作業中に受けた力の ピーク值についてプロットしたものが Fig. 16 である. 10 回試 行を行ったので, 図中にはその平均值, 最大値, 最小值を示して ある. 手先を動かさない場合は平均 $71.3[\mathrm{~N}]$ の負荷が生じてい た。これに対して制御 1 は平均值に扔いて手先を動かさない場 合の負荷から $45.5 \%$ 減の $38.9[\mathrm{~N}]$ であり大幅な負荷軽減ができ ている．さらに制御 2 では $70.0 \%$ 減の $21.4[\mathrm{~N}]$ となり，いずれ の対策も効果的に作用していることが分かった。 また制御 2 の $21.4[\mathrm{~N}]$ とヒトの取り付けの $15.0[\mathrm{~N}]$ という值を比べるとその 差はわずか $6.4[\mathrm{~N}]$ であり，ヒトにかなり近い性能を実現してい る. また試行ごとの值のばらつきの幅を評価するため, Fig. 16 には最大值と最小值もプロットしており，これを見るとその差 はロボットの取り付けでは平均值の 2 割以内, ヒトの取り付け では 3 割以内となっており, 取り付け時の負荷の值はある程度 


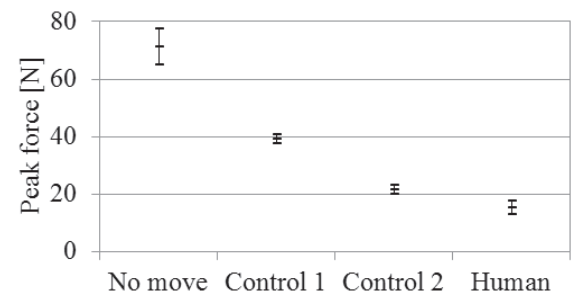

Fig. 16 Peak forces in assembly processes

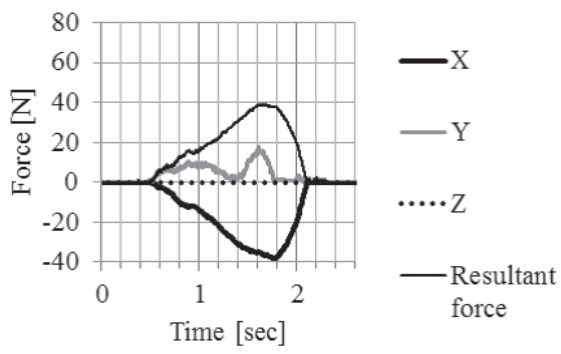

(a) Force

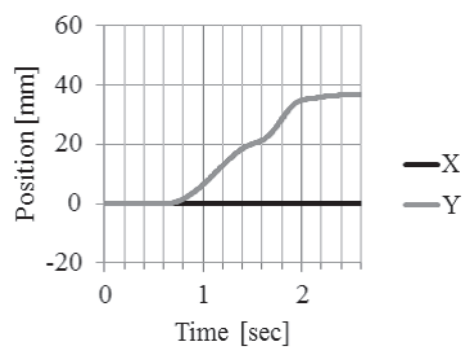

(b) Position

Fig. 17 Example of measurement results in "Control 1"

安定しているということも確認された.

続いて，それぞれの方法についてより詳細に結果を見てみる。 制御 1 における取り付け時の負荷の時間変化とロボットの手先 位置の時間変化の例を Fig. 17 に示す。制御 1 の結果である Fig. 17 (a) と手先を動かさない Fig. 11 (a) を比べると, 元々Y 方向が全体の合力の中で最も大きな成分であり $65.8[\mathrm{~N}]$ が観測 されていたが, 制御 1 では Y 方向にダンピング制御を行ったこ とで $\mathrm{Y}$ 方向の力が $73.2 \%$ 低減されて $17.6[\mathrm{~N}]$ となっている. そ の結果, 3 方向の合力の中では残った X 方向の力が支配的になっ ている. ヒトの測定例である Fig. 11 (b) 抢よび Fig. 12 と比較 する. 制御を行った Y 方向については手先位置がプラスの方向 に動き続けており，負荷についてもある程度小さい值に抑えら れて扔りヒトの動力学特性と定性的には同様と言える。ただし その手先の移動量や負荷の低減量を見るとヒトの值よりやや小 さく, Y 方向の移動量はヒトが $51.0[\mathrm{~mm}]$ のところ制御 1 では $36.7[\mathrm{~mm}]$ と $14.7[\mathrm{~mm}]$ ほどの差があり，Y 方向の負荷もヒト が $3.7[\mathrm{~N}]$ であるのに対して制御 1 では $17.6[\mathrm{~N}]$ であった。こ のことからロボットの手先の移動量が不十分であり負荷を逃が しきれていない状況にあるのではないかと考えられる.式（1） を見ると $d_{y}$ の值を大きくすればより大きな速度を出すように なり移動量も増えることが期待されるが，一方で $d_{y}$ を大きくし

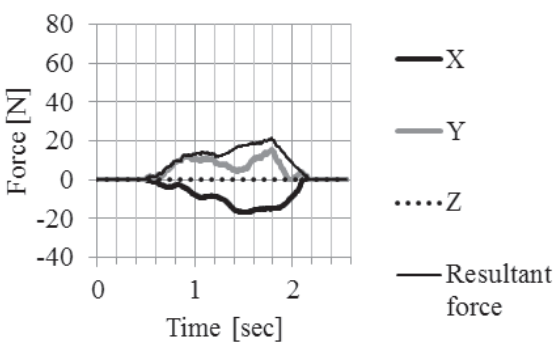

(a) Force

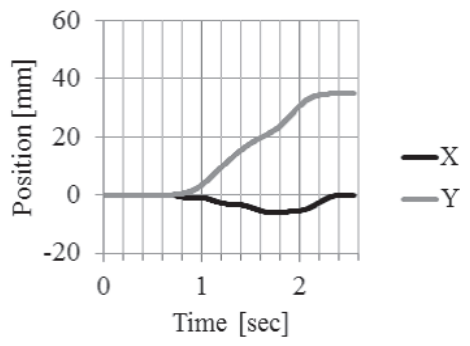

(b) Position

Fig. 18 Example of measurement results in "Control 2"

ていくと手先が振動し始めて不安定化する. この不安定化の原 因についてはロボットの応答性能によるものと考えられる。ロ ボットのカデータと位置デー夕をより詳細に見比べると, 最初 に力を検知してから実際に動作を開始するまで 0.1 秒程度の時 間遅れが観測された。一般にむだ時間はシステムを不安定化さ せる要因になるため，このことが $d_{y}$ を十分大きくできない原 因になっていると考えられ，そのためにY方向の負荷がこれ以 上は下がらなかったものと考えられる。

制御 2 での測定例が Fig. 18 である. 制御 1 の Fig. 12 と比 較すると, 制御 2 では X 方向に剛性制御を行うことで制御 1 で残っていた X 方向の力についても低減することができ，合力 をさらに抑えることに成功している，またヒトの測定例である Fig. 11 (b), Fig. 12 と比較すると, Y 方向は制御 1 と同様で, ヒトより手先の移動量がやや少なく手先に作用する力も残って いるものの定性的にはヒトと同様の振る舞いを実現している. そしてX 方向は, ヒトの X 方向の力が $-16.7[\mathrm{~N}]$ となってい たのに対して制御 2 では $-16.9[\mathrm{~N}]$ でありヒトとほぼ同じ負荷 となって抢り，手先位置もヒトの一度マイナス方向に振れた後 に最終的に元の位置に戻ってくる動きが制御 2 でうまく再現さ れている.

以上，本章では 2 種類の制御法方法について実際にロボット に実装して性能評価を行ってその有効性を確認した．特にX 方 向，Y方向の両方に力制御を行った場合に执いてはヒトに近い 性能を実現していることを示すとともに，ヒトとの性能差につ いてはロボットの速度制御の応答性能が要因になっている可能 性があることを指摘した。

\section{6. 結言}

本研究では円柱状のワークにリング状のゴムパッキンを取り 
付ける作業をロボットで実現するため, その取り付け方法の検 討を行った。 パッキンは傷などに関してシビアであり, その取り 付け過程で傷がつくことを防ぐためにパッキンに過度の負荷を かけないような工夫が求められる。 そこで熟練作業者が作業を 行った際の手先の位置と力のデー夕を定性的に解析することに より熟練作業者の動特性を基にした力制御を構築して負荷軽減 を試みた。 力制御パラメータについては滑降シンプレックス法 による最適化で決定し，ロボットの特性も考慮した制御とした． そして以上の効果を検証するための実験を行い，提案手法によ りヒトに近い性能を実現していることを確認した。今後の課題 として，パッキンやワークが変わった場合の検討が挙げられる. 本手法のうち, 熟練作業者から抽出した力制御手法については そのまま適用できることが予想されるが, 力制御パラメータに ついてはパッキンやワークの種類が変わることで新たに設定し 直す必要があり，パッキンやワークの種類が多いと手間な作業 となる。そここで例えば最適化の初期值をうまく選ぶことで最適 化を素早く収束させる方法の検討やロボットが不安定化する条 件に関する理論的あるいは実験的な検討など，パッキンやワー クの変更に対応しやすくする手法について今後検討する.

\section{参 考 文 献}

[1] 福本, 濱田, 坂東, 竹中, 小林：“パッキン取付作業のロボット化に 関する検討”，知能メカトロニクスワークショップ講演論文集，M1-1, 2013.

[2] 福本, 濱田, 竹中, 坂東, 小林：“パッキン取り付け作業に执ける力 制御を用いた負荷軽減の検討”, 日本ロボット学会学術溝演会予稿集, 3N1-05, 2014.

[3] 福本, 原田, 河井, 坂東, 竹中：“熟練作業の動力学特性に基づいた パッキン取り付け作業”, 第 34 回日本ロボット学会学術講演会予稿 集 DVD-ROM, 3E1-04, 2016.

[4] 浅田, 出海: “作業者の動作計則によるハイブリッド制御のための作業教 示とプログラム生成”, 日本ロボット学会誌, vol.5, no.6, pp.452-459, 1987.

[5] 望月, 松井：“インピーダンス制御を応用したハイブリッド制御の直 接教示法”, 日本ロボット学会誌, vol.12, no.2, pp.328-334, 1994.

[6] 板橋, イエ, 鈴木, 大熊: “隠れマルコフモデルに基づく人間の技能の 獲得”, 計測自動制御学会論文集, vol.34, no.8, pp.890-897, 1998.

[7] 津坂, 岡崎, 小松, 横小路: “人からの手づたえ教示によるロボットアー 厶のその場動作修正法の開発”, 日本機械学会論文集 C 編, vol.78, no.791, pp.2450-2461, 2012.

[8] A. Ajoudani, N.G. Tsagarakis and A. Bicchi: "Tele-Impedance: Towards Transferring Human Impedance Regulation Skills to Robots," Proc. of IEEE Int. Conf. on Robotics and Automation, pp.382-388, 2012.

[9] 田中, 木原, 横小路：“人間の直接教示動作の統計的性質に基づいた 折り紙ロボットの目標軌道とセンサフィードバック則生成法”、日本

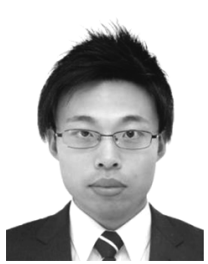

福本靖彦（Yasuhiko Fukumoto）

2008 年大阪大学大学院基礎工学研究科博士前期課程 修了．同年より香川県産業技術センター勤務，2016 年大阪大学大学院基礎工学研究科入学. 産業用口 ボットの応用に関する研究に従事. 日本機械学会の 会員.

(日本ロボット学会学生会員)
ロボット学会誌, vol.27, no.6, pp.685-695, 2009.

[10] A.X. Lee, H. Lu, A. Gupta, S. Levine and P. Abbeel: "Learning Force-Based Manipulation of Deformable Objects from Multiple Demonstrations," Proc. of IEEE Int. Conf. on Robotics and Automation, pp.177-184, 2015.

[11] 榎本，杉本，松本：“マスタ・スレーブシステムを用いた磨き動作の 作業モデルの獲得（作業モデルに基づくモデルベースト制御の統一的 手法)”，日本機械学会論文集 C 編，vol.68, no.676,pp.3620-3627, 2002.

[12] 尹, 末廣, 音田, 北垣: “バイラテラル遠隔操作を利用したタスクスキルト ランスファー手法”, 日本ロボット学会誌, vol.25, no.1, pp.155-165, 2007.

[13] E. Gribovskaya, A. Kheddar and A. Billard: "Motion Learning and Adaptive Impedance for Robot Control during Physical Interaction with Humans," Proc. of IEEE Int. Conf. on Robotics on Automation, pp.4326-6332, 2011.

[14] M. Racca, J. Pajarinen, A. Montebelli and V. Kyrki: "Learning In -Contact Control Strategies from Demonstration," Proc. of IEEE/RSJ Int. Conf. on Intelligent Robots and Systems, pp.688-695, 2016.

[15] 辻：“ヒトの上肢運動のしなやかさを計測する”，計測と制御，vol.35, no.9, pp.689-695, 1996.

[16] M.S. Erden and A. Billard: "End-point Impedance Measurements at Human Hand during Interactive Manual Welding with Robot," Proc. of IEEE Int. Conf. on Robotics and Automation, pp.126-133, 2014.

[17] 平井: “柔軟物操作”, 日本ロボット学会誌, vol.16, no.2, pp.136-139, 1998.

[18] ラミレス, 原田, 吉田: “柔軟性を有するリング状部品の組み立て動作 計画”，ロボティクス・メカトロニクス講演会講演概要集，1P1-P04, 2014.

[19] 村瀬，松原，杉本，田中，山崎：“ゴムの粘弾性に着目した双腕ロボッ トによる輪ゴムかけ動作計画”, 第 34 回日本ロボット学会学術講演 会予稿集 DVD-ROM, 3Z2-03, 2016.

[20] 株式会社デンソー：O リング組み付け装置，特開 2004-138226, 20045-13.

[21] 三菱電機株式会社：ロボットハンドシステム，特開 2009-291859, 2009-12-17.

[22] SCHUNK GmbH \& Co. KG, ORG, https://schunk.com/jp_en/ gripping-systems/series/org/.

[23] 日産自動車株式会社：リング部品の装着方法及び装着装置, 特開 200552960, 2005-3-3.

[24] 株式会社ガスター：弾性リング装着治具および弾性リング装着方法, 特開 2006-255886, 2006-9-28.

[25] W.H. Press, W.T. Vetterling, S.A. Teukolsky and B.P. Flannery（丹慶，奥村，佐藤，小林訳）：Numerical Recipes in C [日本 語版]. pp.295-299, 技術評論社, 1993.

[26] S. Hirai, T. Inatsugi and K. Iwata: "Learning of admittance matrix elements for manipulative operations," Proc. of Int. Conf. on Intelligent Robots and Systems, pp.763-768, 1996.

[27] 山野辺, 前田, 新井, 渡邊, 加藤, 佐藤, 畑中：“サイクルタイムを考 慮した力制御パラメータ設計”，日本ロボット学会誌，vol.24, no.4, pp.554-562, 2006.

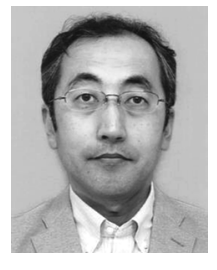

原田研介（Kensuke Harada）

1997 年京都大学大学院工学研究科博士後期課程修 了. 同年広島大学工学部助手. 2002 年産業技術総 合研究所知能システム研究部門研究員，2005 年か ら 1 年間 Stanford 大客員研究員, 2013 年同研究 所タスクビジョン研究グループ長, 2016 年大阪大 学大学院基礎工学研究科教授，同年産業技術総合研 究所クロスアポイントメントフェローを兼務, 現在に至る. ロボット ハンドによる把持や操りに関する研究に従事. IEEE，計測自動制御 学会, 日本機械学会, システム制御情報学会の会員. 博士 (工学). 